\title{
Physiologycal Water-use Efficiency in Plants: An Opinion
}

\author{
Ruiz-Nieto JE* \\ Department de Agronomía, University de Guanajuato Campus Irapuato-Salamanca, México
}

Submission: December 01, 2017; Published: December 20, 2017

"Corresponding author: Ruiz-Nieto JE, Department de Agronomía, University de Guanajuato Campus Irapuato-Salamanca, México, Email: jorge.ruiz@ugto.mx

\section{Opinion}

The most important components of climate change are the increase in the temperature and concentration of $\mathrm{CO} 2$ as well as the alteration on the temporal and spatial distribution of the rainfall which limits the water availability [1]. Consequently, the agriculture is extremely susceptible to the negative effects of climate change. The most plausible predictions for the next 50 years indicate increases in the average annual temperature from 1 to $2.5{ }^{\circ} \mathrm{C}$ [2], this will increase the evapotranspiration rates and the water requirements to produce, mainly in the warmer regions. Besides, water is a limited resource and the agriculture consumes the $78 \%$ [3], however, $97 \%$ of the water absorbed by plants is transpired into the atmosphere by stomata [4].

A crucial step in the colonization of terrestrial environments by plants was the evolution of elements that allow them to control the water loss while continued fixing $\mathrm{CO} 2$; thus, plants developed different response to water limitation that altogether ensure the survival of the specie, increase the ability to access the available water and improve the efficiency on its use. The term Water-Use Efficiency (WUE) emerged from the concept of resistance and tolerance to water limitation [5]. A way to mitigate the effects of climate change, reduce the water consumption and improve the tolerance to waters stress is through the generation of cultivars with a high WUE.

According to Yoo et al. [6], WUE might be improved increasing the $\mathrm{CO} 2$ assimilation relative to the transpiration or reducing the transpiration relative to $\mathrm{CO} 2$ the assimilation. Therefore, through the understanding and manipulation of the genes that are directly related to the photosynthesis, transpiration, conductance and stomatal density it would be possible to improve the physiological performance related to WUE. According to Moreno [7], cultivars with a high WUE will also have a higher yield under limited conditions. Currently, diverse groups are advancing on the researches to improve this complex trait, however, unlike other challenges that modern agriculture has faced, this time the solutions must be considered in the frame work that for 2050 the world population will increase to nine billion people [8].
Despite the future need to produce more food for a growing population, the water resources destined to agriculture will be increasingly limited which will compromise the food security of many regions. The development of efficient agricultural technology should be a priority considering the two components that shape agriculture, the agronomy and biology. For the second, it is necessary to develop cultivars with a positive balance between the carbon assimilation and the water losses, as well as trans locate the gained resources towards the formation of biomass, fruits and seeds according to the economical interest of each crop. The improvement of WUE can be addressed by many developed strategies and technologies, as take advantage of available diversity for each specie or even if it is necessary to create the diversity through crosses and/or artificial means, use the positive effects of heterosis, perform selections based on the genotype with molecular markers increasingly efficient and specific, perform point genetic modifications each time with greater effects on the phenotype. However, there will be limits to where the biology can be manipulated and no global problem as important as increasing the world production of food with less water resources will be resolved without greater social will. As conclusion, the expected blue revolution will not happen without an integral vision in which agriculture has a fundamental role.

\section{References}

1. Crimmins SM, Dobrowski SZ, Greenberg JA, Abatzoglou JT, Mynsberge AR (2011) Changes in climatic water balance drive downhill shifts in plant species optimum elevations. Science 331(6015): 324-327.

2. IPCC (2007) Climate change: the physical science basis. Intergovernmental Panel on Climate Change, NewYork, USA, pp. 996.

3. de Fraiture C, Wichelns D (2010) Satisfying future water demands for agriculture. Agric Water Manag 97: 502-511.

4. Taiz L, Zeiger E (2006) Plant Physiology. (4th edn), Sinauer Associates, Sunderland, MA, USA, pp. 571-591.

5. Passioura J (2006) Increasing crop productivity when water is scarcefrom breeding to field management. Agric Water Manag 80(1-3): 176196. 
6. Yoo CY, Pence HE, Hasegawa PM, Mickelbart MV (2009) Regulation of transpiration to improve crop water use. Crit Rev Plant Sci 28(6): 410431.

7. Moreno LP (2009) Respuesta de las plantas al estrés por déficit hídrico. Una revisión. Agron Colom 27(2): 179-191.
8. Godfray HCJ, Beddington JR, Crute IR, Haddad L, Lawrence D, et al (2010) Food security: the challenge of feeding 9 billion people. Science 327(5967): 812-818.

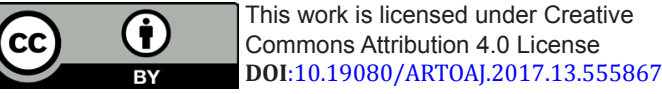

\author{
Your next submission with Juniper Publishers \\ will reach you the below assets \\ - Quality Editorial service \\ - Swift Peer Review \\ - Reprints availability \\ - E-prints Service \\ - Manuscript Podcast for convenient understanding \\ - Global attainment for your research \\ - Manuscript accessibility in different formats \\ ( Pdf, E-pub, Full Text, Audio) \\ - Unceasing customer service
}

Track the below URL for one-step submission https://juniperpublishers.com/online-submission.php 